\title{
Trilobites and gastropods from Silurian carbonate mounds in Valdemar Glückstadt Land, eastern North Greenland
}

\author{
Philip D. Lane and John S. Peel
}

P. D. L., Department of Geology, The University, Keele, Staffs. ST5 5BG, U.K.

J. S. P., Grønlands Geologiske Undersøgelse, Øster Voldgade 10, DK-1350 København K, Danmark.

Silurian carbonate mounds were reported from Valdemar Glückstadt Land, eastern North Greenland (lat. $82^{\circ} \mathrm{N}$, long. $22^{\circ} \mathrm{W}$ ) by Peel $(1980)$ following reconnaissance geological mapping in 1979 . The localities were revisited during August 1980 when a complex of carbonate mounds and patch reefs rooted in bedded Silurian limestone and overlain by black graptoliferous shales of latest Early Silurian age, similar to those known elsewhere from eastern North Greenland (Christie \& Peel, 1977; Lane \& Thomas, 1979; Mabillard, 1980) was noted. Trilobites and gastropods are well represented in the mound faunas, together with stromatoporoids, favositid and rugose corals, pentamerid and other brachiopods, cephalopods and rare bivalves. Crinoid debris is abundant.

The trilobite genera recorded are typical of Silurian carbonate mounds in arctic North America and U.S.S.R. Stenopareia, illaenimorph scutelluids, cf. Ekwanoscutellum and Meroperix dominate, with Hyrokybe, Platylichas, Scotoharpes(?) and a proetid also present. Many of these are known from elsewhere in northern Greenland (Lane, 1972, 1979; Lane \& Thomas, 1979).

Apart from platyceratids, found everywhere in similar facies of this age, the gastropod fauna includes Subulites, Gyronema, Liospira, Megalomphala and less frequent trochiform pleurotomariaceans and onychochilaceans. Most of these genera and many of the species are similarly represented in collections from other parts of northern Greenland.

As is usual with such faunas, precise determination of age is not possible. However, the immediately overlying black shales have a fauna including Monograptus spiralis, $M$. cf. M. parapriodon and Monoclimacis aff. $M$. geinitzi indicating the crenulata Zone of latest Llandovery (late Early Silurian) age. It is considered unlikely that the age of the carbonate mounds differs significantly from this.

\section{References}

Christie, R. L. \& Peel, J. S. 1977: Cambrian-Silurian stratigraphy of Børglum Elv, Peary Land, eastern North Greenland. Rapp. Gronlands geol. Unders. 82, 48 pp.

Lane, P. D. 1972: New trilobites from the Silurian of north-east Greenland. Palaeontology 15, 336-364.

Lane, P. D. 1979: Llandovery trilobites from Washington Land, North Greenland. Bull. Grønlands geol. Unders. 131, $37 \mathrm{pp}$.

Lane, P. D. \& Thomas, A. T. 1979: Silurian carbonate mounds in Peary Land, North Greenland. Rapp. Grønlands geol. Unders. 88, 51-54.

Mabillard, J. E. 1980: Silurian carbonate mounds of south-east Peary Land, eastern North Greenland. Rapp. Grønlands geol. Unders. 99, 57-60.

Peel, J. S. 1980: Geological reconnaissance in the Caledonian foreland of eastern North Greenland with comments on the Centrum Limestone. Rapp. Gronlands geol. Unders. 99, 61-73. 